\title{
An experimental investigation to study combined effect of EGR and tung oil biodiesel blends used for CI engine
}

\author{
G.A.Nagargoje*, K. P. Kolhe and S.S.Ragit \\ JSPM's Imperial College of Engineering \& Research, Wagholi, Pune-14, India \\ Accepted 15 June 2016, Available online 20 June 2016, Special Issue-5 (June 2016)
}

\begin{abstract}
In the current study, the biodiesel is produced from transesterification of tung oil. Properties of biodiesel are very approximate to diesel hence it can be used in diesel engine without any modification but use of biodiesel in CI engine will tends to ptoduce high $\mathrm{NO}_{X}$ emission. Exhaust Gases Recirculation (EGR) is one of the most effective method to reduce such $\mathrm{NO}_{X}$ emission. The study is carried out to investigate the emission and performance characteristics of single cylinder, four stroke, direct injection and water cooled CI engine to observe the effect of different EGR rates and blends of tung oil biodiesel. The rated power and speed of engine were noted down $3.5 \mathrm{KW}$ and $1500 \mathrm{rpm}$ respectively. The engine performances (Thermal efficiency, brake specific fuel consumption and temperature of exhaust gas) and exhaust emissions (oxides of nitrogen, unburned hydrocarbon and Carbon monoxide) has evaluated. The experimental results obtained in each case are compared with baseline data of mineral diesel. Improvements has been found in the performance parameters of the engine as well as exhaust emissions system. Result shows that, brake thermal efficiency increased by $2.16 \%$ with $10 \%$ EGR at partial load for diesel as a fuel used. The reduction in $N O_{X}$ is approximately 400 ppm with application of EGR at high load but HC and CO emissions were found increased same time. The experimental study indicates that Biodiesel and EGR both can be deployed together in CI engines to obtain reduction of $\mathrm{NO}_{X}$ emissions.
\end{abstract}

Keywords: Transesterification, TOME, CI engine, EGR, NOX.

\section{Nomenclature}

ASTM American Society for Testing and Material BTE Brake Thermal Efficiency

CO Carbon Monoxide

CO2 Carbon Dioxide

EGR Exhaust Gas Recirculation

SFC Specific Fuel Consumption

TOME Tung Oil Methyl Ester

HC Hydrocarbons

NOX Nitrogen Oxide

\section{Introduction}

Diesel engine's are more popular because of higher power and better economy hence they mostly used engine for the purpose of transportation. In future limited feed stock of fossil fuels will not able to fulfill the need of rapidly increasing vehicle ownership. Hence investigation of alternative fuel for partial and full replacement of diesel is going on nowdays.

Biodiesel is not a totally new concept because the $1^{\text {st }}$ diesel engine was made run on vegetable oil during A.D. 1900 by Mr. Rudolph Diesel. The direct use of

*Corresponding author: G.A.Nagargoje vegetable oil in diesel engine caused problems like misfire, cold starting and ignition delay. Transterification of vegetable oil with methanol will goin to produce biodiesel and it can be used in diesel engine directly or by blending with diesel. Use of biodiesel in $\mathrm{CI}$ engine will reduce emission of carbon monoxide (CO) and hydrocarbon (HC) but at the same time it will increases $\mathrm{NO}_{\mathrm{X}}$ emission too.

$\mathrm{NO}_{\mathrm{x}}$ emissions are health hazardous hence in recent year's very tight emission legislations on $\mathrm{NO}_{\mathrm{x}}$. has undertaken and in order to meet these legislations it is required to reduce the $\mathrm{NO}_{\mathrm{x}}$ emissions at stret and rigours basis. Higher combustion temperature and $\mathrm{O}_{2}$ concentration are the main causes of $\mathrm{NO}_{\mathrm{X}}$ formation during the combustion occured. Exhaust gases Recirculation is one method to reduce $\mathrm{NO}_{\mathrm{x}}$ formation effectively. Mixing some amount of exhaust gas in to intake air will decrease $\mathrm{O}_{2}$ concentration as well as combustion temperature due to higher specific heat of exhaust gases.

India is the major producer of tung oil which non edible by nature. The total available Tung oil is left unutilized due to various reasons. From the literature survey it has been also observed that there are very less research on tung oil methyl ester. Hence the present study focusing on effect of tung oil biodiesel 
and Exhaust Gas Recirculation (EGR) on performance and emission of CI Engine.

\section{Materials and methods}

This section provides a description of the materials and methodology used for production of biodiesel and CI engine test rig.

\subsection{Materials}

The Tung oil used in this study has been purchased from riddhi chemicals pvt ltd Mumbai. The commercial diesel fuel was purchased from petrol pump which is placed nearer to Imperial College Of Engineering and Research (ICEOR) Wagholi, Pune. Other chemicals, like (Methanol, KOH Catalyst) were procured during experimentation from D Haridas \& Company, katraj, Pune.

\subsection{Methods}

The Biodiesel was produced by transestrification of the tung oil using 6:1 molar ratio of methanol and $1.5 \%$ of $\mathrm{KOH}$.

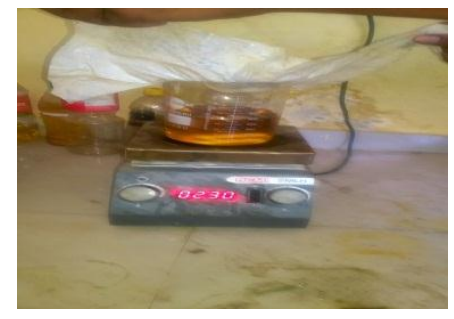

Fig.1Transestrification set up

The transesterification process was carried out as per the procedure described below:

$1 \mathrm{~kg}$ refined Tung oil was taken in a $1000 \mathrm{ml}$ capacity conical flask and heated at $55^{\circ} \mathrm{C}$ selected reaction temperature for $30 \mathrm{~min}$ preheating time maintained. Then $250 \mathrm{ml}$ of methyl alcohol was taken to obtain molar ratio of $6: 1$ and $15 \mathrm{gm}$ of Potassium hydroxide $(\mathrm{KOH})$ and mixed thoroughly. This mixture was added to $1000 \mathrm{gm}$ preheated tung oil and the mixture was placed on magnetic stirrer to carry out reaction for a period of 1 hour at $60^{\circ} \mathrm{C}$ reaction temperature. After that liquid which was a mixture of biodiesel (TOME) and glycerol is poured through separating funnel and allow it to get settling down for further separation of biodiesel and glycerol from each other. The glycerol settled at the bottom of separating funnel was separated by method and called as draining. Then the biodiesel left behind in the funnel was washed with distilled water and allow it to settle down. The water accumulated along with traces of glycerol at the bottom of the separating funnel was drained. Washing of biodiesel is carried out three times to remove the remaining tarces and quantity of glycerol, alcohol and $\mathrm{KOH}$ in the biodiesel mixture.

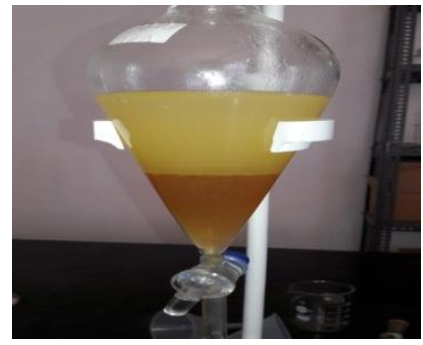

Fig.2Biodiesel glycerol separation

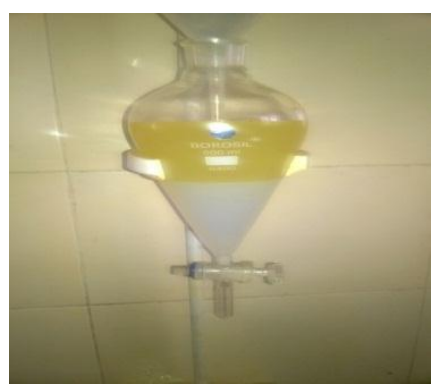

Fig.3 Water washing of biodiesel

Finally washed biodiesel was dried by silica gel to absorbs the moisture and biodiesel in it's final form now become ready to use. Viscosity, density and calorific value were measured by redwood viscometer, hydrometer and bomb calorimeter respectively. The fuel properties of tung oil methyl ester and diesel are summarized in Table 1 as below,

Table 1Properties of Diesel and TOME

\begin{tabular}{|c|c|c|c|}
\hline Property of oil & ASTM std & Diesel & $\begin{array}{c}\text { Tung oil } \\
\text { biodiesel }\end{array}$ \\
\hline Density (kg/m3) & ---- & 830 & 895.8 \\
\hline $\begin{array}{c}\text { Kinematic } \\
\text { viscosity }(\mathrm{cSt})\end{array}$ & 1.9 to6.0 & 3.5 & 4.6 \\
\hline Flash point $\left({ }^{\circ} \mathrm{C}\right)$ & $>130$ & 56 & 180 \\
\hline Fire point, $\left({ }^{\circ} \mathrm{C}\right)$ & $>153$ & 62 & 194 \\
\hline Cloud point $\left({ }^{\circ} \mathrm{C}\right)$ & -3 to -12 & -10 & -2 \\
\hline Pour point, $\left({ }^{\circ} \mathrm{C}\right)$ & -15 to 10 & -6 & -6 \\
\hline $\begin{array}{c}\text { Calorific } \\
\text { value }(\mathrm{kJ} / \mathrm{kg})\end{array}$ & $>33000$ & 42000 & 38947 \\
\hline
\end{tabular}

\section{Experimental setup and instrumentation}

In the present experimental work single cylinder, four stroke and CI engine has used. The engine was Kirloskar made and water cooled type. The engine is connected to Eddy current dynamometer for the measurement of brake power. Engine torque was measured using load cell. The specifications of engine are given in Table 2 .

Table 2 Engine Specification

\begin{tabular}{|c|c|}
\hline Make & Kirloskar Engine \\
\hline Model & TV1 \\
\hline No of cylinders & 1 \\
\hline No of strokes & 4 \\
\hline Cylinder Bore & $87.5 \mathrm{~mm}$ \\
\hline
\end{tabular}




\begin{tabular}{|c|c|}
\hline Stroke length & 110 \\
\hline Type of cooling & Water cooled \\
\hline Power & $3.5 \mathrm{KW}$ \\
\hline Rated Speed & $1500 \mathrm{rpm}$ \\
\hline Compression Ratio & $18: 1$ \\
\hline Loading device & $\begin{array}{c}\text { Eddy current } \\
\text { dynamometer }\end{array}$ \\
\hline
\end{tabular}

The experimental set up is shown in fig.4. It has standalone panel box consisting of air box, fuel tank, manometer, fuel measuring unit, transmitters for air and fuel flow measurements, RTD and thermocouples used for air and water temperature measurement at various points. Signals from sensors are interfaced by computer through high speed data acquisition device.

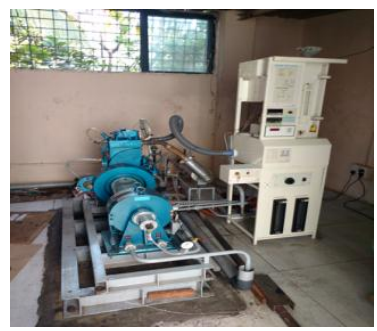

Fig.4 Experimental Setup

Rotameters are used for flow measurment and calorimeter for water cooling. The exhaust gases emissions were measured by using AIRREX HG-540 exhaust gas analyser. Water cooled EGR cooler is connected to engine by means of appropriate plumbing and used for cooling and recirculation of exhaust gases. The quantity of exhaust gases under recirculation can be controlled by valve fitted in EGR path.

\section{Experimental procedure}

To achieve objective of experimental study engine has put under nroal running conditions. Tests were conducted at $1500 \mathrm{rpm}$ engine speed. B10 and B20 blends of tung oil methyl ester were prepared on volumetric basis. Engine was started at no load and varied to rated load in number of steps. Set of reading is obtained without EGR and with 10\% EGR for pure diesel fuel. Similar set of reading has obtained for B10 and B20 blends of TOME. Engine performance parameters like Brake Thermal Efficiency (BTE), Specific Fuel Consumption (SFC), Exhaust Gas Temperature and emission parameters such as Nitrogen monoxide $\left(\mathrm{NO}_{\mathrm{x}}\right)$, Carbon monoxide (CO), Unburned Hydrocarbons (HC) were measured during this test. Then engine parameters were compared for different blends and EGR combinations prepared and put in to test.

\section{Results and discussion}

In this section fuel properties are discussed an dultimatley to study their impact on Engine performance. Emission data is analyzed and presented in graphical form to studythe aspects like thermal efficiency, BSFC, exhaust gas temperature, $\mathrm{HC}, \mathrm{CO}, \mathrm{CO}$, $\mathrm{NO}_{\mathrm{X}}, \mathrm{O}_{2}$ emissions etc.

\subsection{Fuel properties}

The experimental results indicated that the density of tung oil methyl ester is slightly high to that of diesel fuel. The kinematic viscosities of diesel and tung oil methyl ester were found respectively, 3.5 and $4.6 \mathrm{cSt}$ at $40^{\circ} \mathrm{C}$. The calorific value of diesel and tung oil methyl ester were found 42 and $38.9 \mathrm{MJ} / \mathrm{kg}$ respectively. The calorific value of tung oil methyl ester is $7.2 \%$ less in the comparision o diesel fuel. The tung oil methyl ester was found to have higher flash and fire point than diesel fuel. Cloud point of tung oil methyl ester is higher than that of diesel.

\subsection{Effects on engine performance}

5.2.1 Brake thermal efficiency (BTE)

Table 3 Brake thermal efficiency (\%)

\begin{tabular}{|c|c|c|c|c|}
\hline \multirow{2}{*}{ Fuel } & \multirow{2}{*}{ EGR \% } & \multicolumn{3}{|c|}{ Load (kg) } \\
\cline { 3 - 5 } & & $\mathbf{4}$ & $\mathbf{8}$ & $\mathbf{1 2}$ \\
\hline \multirow{2}{*}{ Diesel } & 0 & 16.55 & 25.46 & 28.51 \\
\cline { 2 - 5 } & 10 & 18.26 & 27.62 & 28.54 \\
\hline \multirow{2}{*}{ B10 } & 0 & 16.83 & 25.56 & 28.81 \\
\cline { 2 - 5 } & 10 & 18.14 & 26.28 & 28.85 \\
\hline \multirow{2}{*}{ B20 } & 0 & 17.94 & 25.75 & 28.82 \\
\cline { 2 - 5 } & 10 & 18.04 & 26.98 & 28.85 \\
\hline
\end{tabular}

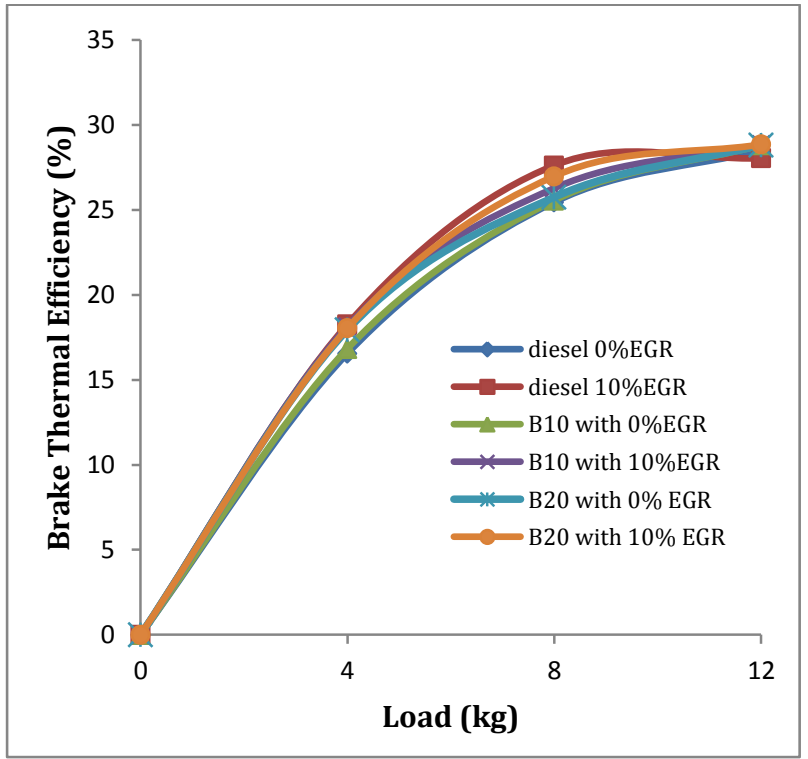

Fig.5 Variation of Brake thermal efficiency with load

Fig.5 indicates that efficiency slightly increases with respect to lower load and EGR but it will not affecting as significantly as loading will set forth for higher magnitude. At lower load exhaust gas contains higher amount of oxygen and thus exhaust gases are recirculated to cylinder and unburned hydrocarbons in 
exhaust gas will get sufficient oxygen for burning. In other hand when loading magnitude is higher, the presence of less oxygen concentration and re-burning of unburned hydrocarbon is not possible. Maximum brake thermal efficiency found $28.85 \%$ at full load for B20 blending with EGR.

\subsubsection{Specific Fuel Consumption (SFC)}

Table 4 Specific Fuel Consumption (kg/kWh)

\begin{tabular}{|c|c|c|c|c|}
\hline \multirow{2}{*}{ Fuel } & \multirow{2}{*}{ EGR \% } & \multicolumn{3}{|c|}{ Load (kg) } \\
\cline { 3 - 5 } & & $\mathbf{4}$ & $\mathbf{8}$ & $\mathbf{1 2}$ \\
\hline \multirow{2}{*}{ Diesel } & 0 & 0.52 & 0.34 & 0.3 \\
\cline { 2 - 5 } & 10 & 0.47 & 0.31 & 0.31 \\
\hline \multirow{2}{*}{ B10 } & 0 & 0.51 & 0.33 & 0.29 \\
\cline { 2 - 5 } & 10 & 0.45 & 0.32 & 0.3 \\
\hline \multirow{2}{*}{ B20 } & 0 & 0.48 & 0.33 & 0.3 \\
\cline { 2 - 5 } & 10 & 0.48 & 0.32 & 0.3 \\
\hline
\end{tabular}

Fig. 6 represents variation of SFC with respect to load at different blends with and without EGR. The results show that the SFC decreases with increase in the magnitude of load found. Further observations are elaborating, SFC fuel consumption is reduced with application of EGR at lower loads but at higher load there is no considerable change in SFC has foundd. It is also observed that there is no significant change in SFC with and without blend B20 over imply over entire range of load. Maximum reduction in SFC $13.46 \%$ has been found at lower load with blend B10 and 10\% EGR as compared to diesel without EGR used at all.

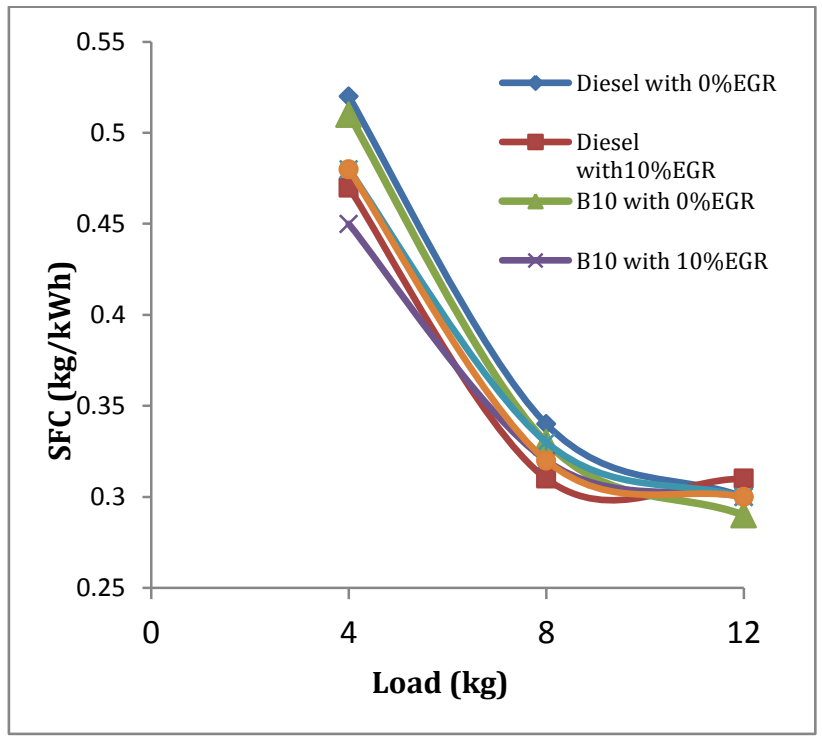

Fig.6 Variation Specific Fuel Consumptionwith load

\subsubsection{Exhaust Gas Temperature}

Trends to elaborate the relationship between exhaust gas temperature with load is shown in Fig. 7. It has been observed that exhaust gas temperature increases with respect to increase in load taken place.
Table5 Exhaust Gas Temperature $\left({ }^{\circ} \mathrm{C}\right)$

\begin{tabular}{|c|c|c|c|c|c|}
\hline \multirow{2}{*}{ Fuel } & \multirow{2}{*}{$\begin{array}{c}\text { EGR } \\
\mathbf{\%}\end{array}$} & \multicolumn{4}{|c|}{ Load (kg) } \\
\cline { 3 - 6 } & 0 & $\mathbf{0}$ & $\mathbf{4}$ & $\mathbf{8}$ & $\mathbf{1 2}$ \\
\hline \multirow{2}{*}{ Diesel } & 0 & 126.96 & 199.83 & 260.53 & 341.81 \\
\cline { 2 - 6 } & 10 & 168.46 & 204.13 & 258.77 & 337.07 \\
\hline \multirow{2}{*}{ B10 } & 0 & 175.88 & 217.20 & 266.71 & 329.54 \\
\cline { 2 - 6 } & 10 & 202.71 & 220.78 & 269.09 & 344.12 \\
\hline \multirow{2}{*}{ B20 } & 0 & 123.13 & 192.37 & 255.63 & 333.94 \\
\cline { 2 - 6 } & 10 & 192.47 & 214.16 & 265.38 & 338.21 \\
\hline
\end{tabular}

The exhaust gas temperature increased with EGR at lower load but for higher load there is no considerable changes has comes to see. The lowest exhaust gas temperature is recorded as $123.13^{\circ} \mathrm{C}$ for no load and B20 blend. The maximum increment in exhaust gas temperature due to EGR is $69.34^{\circ} \mathrm{C}$ and has observed for same load and blend.

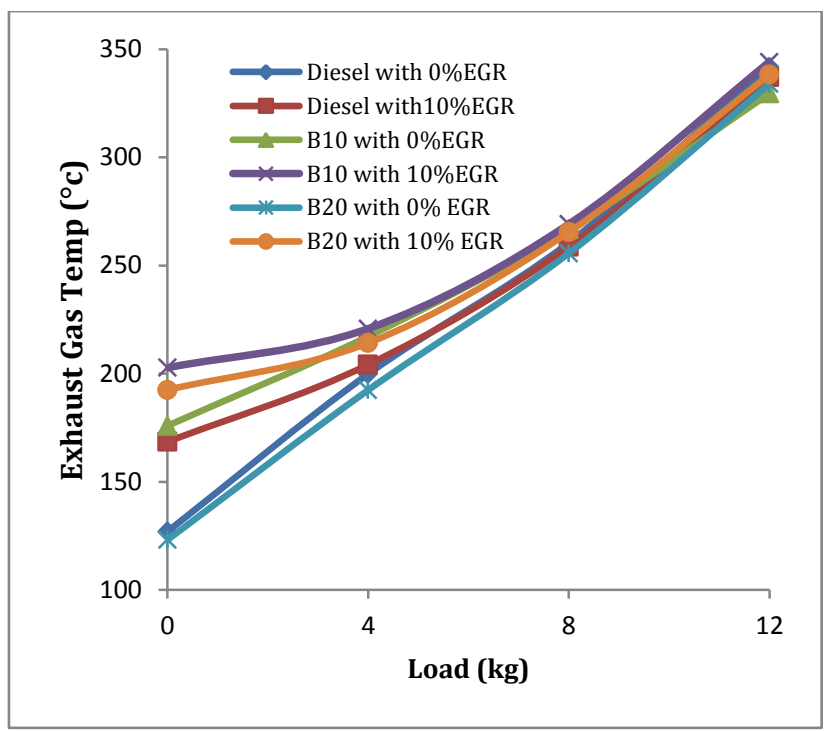

Fig. 7 Exhaust Gas Temperature with load

\subsection{Effect on engine emission}

\subsubsection{Unburned Hydrocarbon emission}

Effect of EGR on unburned hydrocarbon emission is presented in Fig. 8. It indicates that $\mathrm{HC}$ emission increases as load increases. It is also observed that HC emission are higher with EGR as compared to without EGR recommended for all blends applicable to deal with high load but for low load there is no significant effect of EGR on HC emission was found. This may be due to lower amount of oxygen in re-circulated exhaust gas at higher load which causes incomplete combustion as explained earlier.

Table 6 Unburned Hydrocarbon emissions (ppm)

\begin{tabular}{|c|c|c|c|c|c|}
\hline \multirow{2}{*}{ Fuel } & \multirow{2}{*}{ EGR \% } & \multicolumn{4}{|c|}{ Load (kg) } \\
\cline { 3 - 6 } & & $\mathbf{0}$ & $\mathbf{4}$ & $\mathbf{8}$ & $\mathbf{1 2}$ \\
\hline \multirow{2}{*}{ Diesel } & 0 & 14 & 6 & 9 & 19 \\
\cline { 2 - 6 } & 10 & 16 & 17 & 15 & 27 \\
\hline
\end{tabular}




\begin{tabular}{|c|c|c|c|c|c|}
\hline \multirow{2}{*}{ B10 } & 0 & 11 & 9 & 16 & 23 \\
\cline { 2 - 6 } & 10 & 15 & 23 & 20 & 36 \\
\hline \multirow{2}{*}{ B20 } & 0 & 15 & 17 & 14 & 22 \\
\cline { 2 - 6 } & 10 & 14 & 16 & 17 & 34 \\
\hline
\end{tabular}

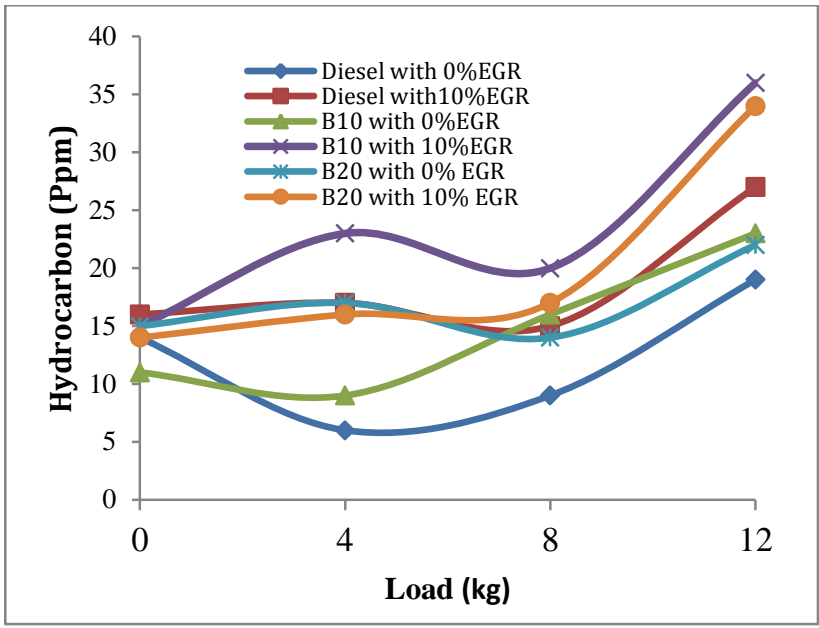

Fig.8 Variation of Unburned Hydrocarbon emissions with load

\subsubsection{Carbon monoxide emission}

Table 7 Carbon monoxide emission (\%)

\begin{tabular}{|c|c|c|c|c|c|}
\hline \multirow{2}{*}{ Fuel } & \multirow{2}{*}{$\begin{array}{c}\text { EGR } \\
\mathbf{\%}\end{array}$} & \multicolumn{4}{|c|}{ Load (kg) } \\
\cline { 3 - 6 } & 0 & 0.073 & $\mathbf{4}$ & $\mathbf{8}$ & $\mathbf{1 2}$ \\
\hline \multirow{2}{*}{ Diesel } & 0 & 0.03 & 0.031 & 0.097 \\
\cline { 2 - 6 } & 10 & 0.073 & 0.05 & 0.055 & 0.255 \\
\hline \multirow{2}{*}{ B10 } & 0 & 0.078 & 0.03 & 0.037 & 0.096 \\
\cline { 2 - 6 } & 10 & 0.083 & 0.06 & 0.063 & 0.245 \\
\hline \multirow{2}{*}{ B20 } & 0 & 0.082 & 0.04 & 0.038 & 0.094 \\
\cline { 2 - 6 } & 10 & 0.086 & 0.05 & 0.048 & 0.224 \\
\hline
\end{tabular}

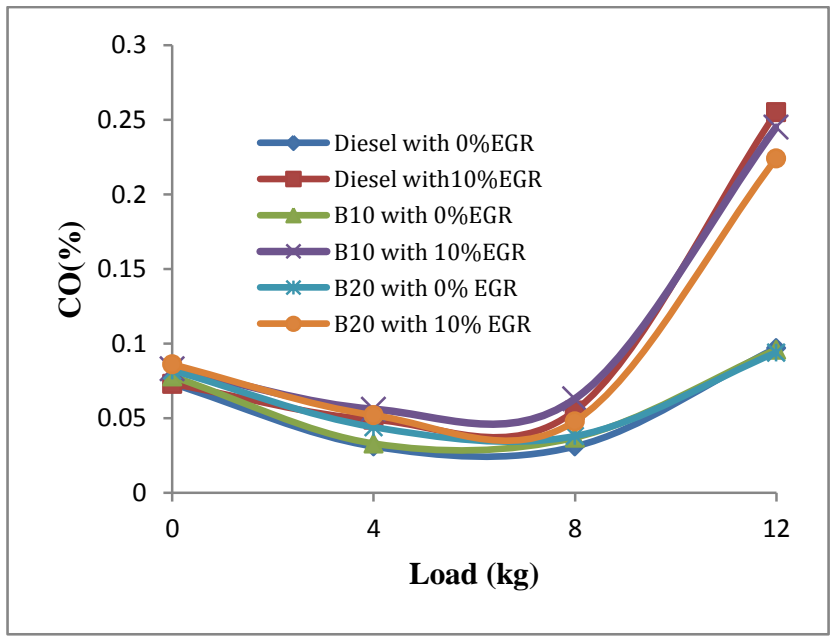

Fig.9 Variation of Carbon monoxide emission with load

From Fig.9 It is observed that at lower load there no large changes in $\mathrm{CO}$ emission has taken place with and without EGR but at high load CO emissions are higher with the effect of EGR and that is considearble. Less oxygen concentration in exhaust gas at higher load cause incomplete combustion and results in higher $\mathrm{CO}$ emission. At full load condition with 10\% EGR, CO emission increased by $0.158,0.149$ and 0.13 for diesel, $\mathrm{B} 10$ and $\mathrm{B} 20$ respectively.

\subsection{3 $\mathrm{NO}_{\mathrm{X}}$ emissions}

Table 8 NOx emissions (ppm)

\begin{tabular}{|c|c|c|c|c|c|}
\hline \multirow{2}{*}{ Fuel } & \multirow{2}{*}{ EGR \% } & \multicolumn{4}{|c|}{ Load (kg) } \\
\cline { 3 - 6 } & & $\mathbf{0}$ & $\mathbf{4}$ & $\mathbf{8}$ & $\mathbf{1 2}$ \\
\hline \multirow{2}{*}{ Diesel } & 0 & 192 & 1053 & 1137 & 773 \\
\cline { 2 - 6 } & 10 & 395 & 806 & 776 & 395 \\
\hline \multirow{2}{*}{ B10 } & 0 & 191 & 1013 & 1218 & 894 \\
\cline { 2 - 6 } & 10 & 376 & 833 & 806 & 433 \\
\hline \multirow{2}{*}{ B20 } & 0 & 240 & 1345 & 1202 & 823 \\
\cline { 2 - 6 } & 10 & 409 & 885 & 786 & 464 \\
\hline
\end{tabular}

Fig. 10 show effect of EGR on reduction in $\mathrm{NO}_{\mathrm{X}}$ emission which is main advantage of EGR. It has been observed that $\mathrm{NO}_{\mathrm{x}}$ emission increases with increment in load and blend percent of biodiesel simutanioulsy. $\mathrm{NO}_{\mathrm{X}}$ emission decreases with EGR for all type of bending specifications applied over. EGR reduces the $\mathrm{NO}_{\mathrm{x}}$ emissions by decreasing combustion temperature and lowering $\mathrm{O}_{2}$ concentration of the intake air. $\mathrm{NO}_{\mathrm{x}}$ reduction is higher at high load, but with decrease in load, reduction in $\mathrm{NO}_{\mathrm{x}}$ emission also found less, because high oxygen concentration in exhaust gas at lower load. EGR recommended in use, $\mathrm{NO}_{\mathrm{x}}$ emission was reduced approximately by 400 ppm even for heavy loads.

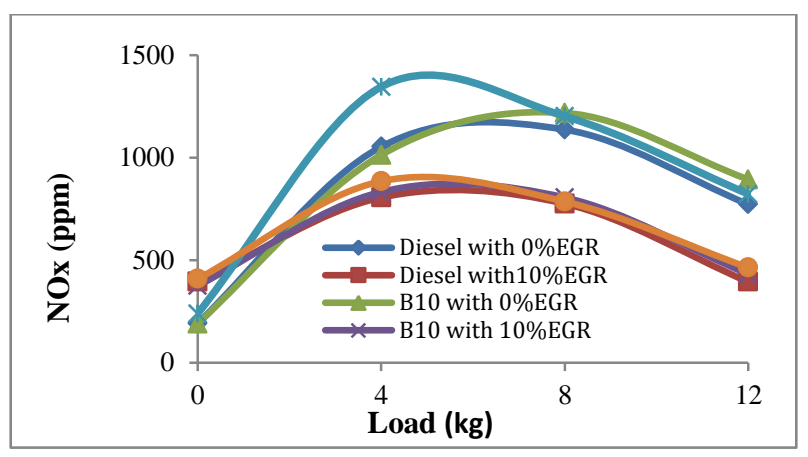

Fig.10 Variation $\mathrm{NO}_{\mathrm{x}}$ emissions with load

\section{Conclusion}

Based on the above results and outcomes measured, following conclusions can be made,

1) The brake thermal efficiency increases slightly at low load with EGR for all combinations. The maximum incremental brake thermal efficiency $2.16 \%$ has observed when diesel and $10 \%$ EGR used for partial load.

2) Diesel with EGR gives more reduction in SFC than blends of TOME with EGR at low load. SFC is reduced by $11.76 \%$ when B10 with EGR is used for lower load. 
3) $\mathrm{HC}$ and $\mathrm{CO}$ emission are higher for blends and EGR for all loads.

4) From partial load to full load condition, CO emission increased considerably with EGR used.

5) EGR reduces the $\mathrm{NO}_{\mathrm{X}}$ emission. This reduction is higher at high loads for all blend specification used.

6) With application of EGR $\mathrm{NO}_{\mathrm{X}}$ emission was reduced approximately by 400 ppm for higher loads.

7) Effect of EGR on emission is found more at high load and less for low load where performance of the engine increased slightly at low load and remains very close to the normal performance for higher load. This leads to conclude that, EGR can be applied at high load to reduce $\mathrm{NO}_{\mathrm{X}}$ emissions at all.

\section{Future scope}

Biodiesel produces more $\mathrm{NO}_{\mathrm{X}}$ emission to surrounding and EGR system reduces such emissions. Biodiesel can be used as fuels for engines with Exhaust Gas Recirculation system has provoed an advantageous to the environment globally.

1) Research can be done to enhance stability of TOME in diesel engine for logn periode of time

2) This work can also be extended in designing manufacturing and study of EGR system which will vary the rate of EGR as per variation in loading conditions will be found.

3) EGR with turbochargers may be used for the studies of performances and emission of engine with the above combinations stated.

4) Artificial Neural Network, Genetic Algorithms may be used to identify the influential factor/parameters.

5) Heat release rate, turbulence parameters, thermodynamic properties and flow field variables can be calculated from the process of simulation with respect to different profile holding prvsion for EGR conditions, with or without.

\section{References}

M. Hassan and Md. AbulKalam,(2013), An overview of biofuel as a renewable energy source: development and challenge, Procedia Engineering, vol. 56, pp. 39 - 53.

B. De and R. Panua, (2014), An experimental study on performance and emission characteristics of vegetable oil blends with diesel in a direct injection variable compression ignition engine, Procedia Engineering, vol. 90, pp. $431-438$.

X. Zhang and W. Huang, (2011), Biodiesel Fuel Production through Transesterification of Chinese Tallow Kernel Oil Using KNO3/MgO Catalyst. Procedia Environmental Sciences, vol. 15, pp. $11757-762$

S. Ragit, S. Mohapatra, P. Gill and K. Kundu, (2012), Comparative study of engine performance and exhaust emission characteristics of a single cylinder 4-stroke $\mathrm{Cl}$ engine operated on the esters of hemp oil and neem oil Indian Journal of Engineering \& Materials Sciences, Vol. 18, pp. 204-210.

K. NanthaGopal, A. Pal, S. Sharma, C. Samanchi, K. Sathyanarayanan, T. Elango, (2014), Investigation of emissions and combustion characteristics of a CI engine fuelled with waste cooking oil methyl ester and diesel blends, Alexandria Engineering Journal, vol.53, pp. 281287.

J. Hussain, K. Palaniradja, N. Alagumurthi, R. Manimaran, (2012), Effect of Exhaust Gas Recirculation (EGR) on Performance and Emission characteristics of a Three Cylinder Direct Injection Compression Ignition Engine, Alexandria Engineering Journal, vol.51, pp. 241-247.

B. Jothithirumal and E. Jamesgunasekaran, (2012), Combined Impact of Biodiesel and Exhaust Gas Recirculation (EGR) on $\mathrm{NO}_{\mathrm{x}}$ Emission in Diesel Engine,Procedia Engineering,Vol. 38, pp.1457-1466.

S. Ragit, S. Mohapatra, P. Gill and K. Kundu, (2012), Brown hemp methyl ester: Transesterification process and evaluation of fuel properties, Biomass and bio energy, vol 41, pp. 14-20.

V. Achuthanunni and B. Baiju, (2014), Experimental Investigation of a Diesel-Biodiesel Fuelled Compression Ignition Engine with Exhaust Gas Recirculation (EGR) International Journal of Engineering and Advanced Technology (IJEAT),Vol. 4, pp. 7-10. 